\title{
Penyelenggaraan Peradilan Pidana (Studi tentang: Model-Model dan Faktor-Faktor yang Berperan dalam Peradilan Pidana)
}

\author{
Rusli Muhammad
}

\begin{abstract}
The implementation the criminal judicature do not automatically appear, but it appears by models support it. Every model applicated and operated in the system of criminal judicature depend on the model selected, but this model is not something concrete but it is something abstract as reflection of the certain values. The implementation the criminal judicature is diseparable with various kinds of factor influence. The harmonious and qualified correlation from these various factors determine very much on the smoothness and the quality of its out put. The ignorance for one of the factors would result to the failure and the low of the quality about implementation on the criminal judicature. The various kind of models and factors in implementing the criminal judicature woul be tried to expose on this writing.
\end{abstract}

\section{Pendahuluan}

Sebagai Negara Hukum, peradilan mutlak diperlukan sebab dengan Peradilan akan dapat mewadahi dan mengimplementasikan berbagai rumusan-rumusan hukum yang bersifat abstrak ke dalam bentuk konkrit. Melalui peradilan akan terjadi proses-proses hukum sebagai salah satu wujud legitimasi atau pengabsahan atas berbagai perilaku baik dalam hubungan-hubungan individual maupun dalam hubungan kelompok sosial kemasyarakatan.

Hal ini berarti telah terjadi Penyelenggaraan Peradilan Pidana yang tujuannya untuk mewujudkan keadilan, sebagaimana yang dicita-citakan oleh semua pihak. Keadilan adalah menjadi tujuan dalam upaya menelenggarakan peradilan, namun tidak pula menutupi tujuan-tujuan lainnya berupa mewujudkan suatu masyarakat adil dan makmur yang merata material dan spiritual berdasarkan Pancasila sebagai tujuan negara sekaligus menjadi tujuan pembangunan Negara Republlik Indonesia.

Penyelenggaraan peradilan pidana adalah sebuah kebijakan yang berarti kebijakan perlindungan masyarakat (social defence policy). Kebijakan melindungi masyarakat diarahkan kepada perlindungan dari berbagai gangguan terutama gangguan keamanan dan keselamatan jiwa, harta, dan kehormatan. Oleh karenanya, penyelenggaraan peradilan pidana adalah juga sebagai suatu 
usaha: penanggulangan kejahatan dengan menggunakan sarana hukum pidana/penal. Sebenarnya-ipenanggulangan; kejahatan dengan menggunakan hukum pidana/penal bukanlah satu-satunya cara, melainkan dapat pula dengan menggunakan cara atau kebijakan lain yang sifatnya non-penal, misalnya melalui jälur pèdidikan, penyañùnuan sosial; dan peñingkatan taraf kesëhatan -masyaräkat! Adanya jalür non-penal:kàrena dianggap bahwa penggunaan hukum pidana àtau penegakan hukum pidana bukañ satu-satunya cara-yang'ampuh dalam menanggulangi 'kejahatan'. Hal ini wajar karena' pada hakikatnya kejahatan itu merupakan "masalah "kemanusiaan" dan "masalah sosial" yang tidak dapat diatasi semata-mata dengan hukum pidana:'

Penggünaan hukum pidana dalam proses perádilan pada: dasarnya 'merupakan penêgakani hukum pidana itu sendiri, dan ini merupakan bagian dari politik kriminal yaitu suatu 'kebijakan yang rasional guna penänggulangan kejahatan idengan tujuan akhirnya adalah keadilan 'dan kesejahteraan uminat manusia.

- :Penyelenggaraan peradilan sebagai upaya penégakan hukum pidana adalah suatu proses-proses hukum yang 'melibatkan berbagai' komponien atau' fäktor-faktor yang dapat mewarnai: sekaligus-berperan dalam menentukan proses-proses hukum' itu. Tulisan ini akan mencoba mengungkapkan berbagai komponen "itu, "namun sebelum membicarakan faktor-faktor tersebut, tulisan ini terlebih dahulu akan diawali dengan menjelaskan beberapa model-model yang berkembang dalam sistem peradilan pidana.

\section{Model-Model dalam Sistem Peradilan Pidana}

Pada dasarnya ada beberapa model dalam sistem peradilan pidana yang berkembang baik di Negara Kontinental maupun di Negara Anglosaxon. Model ini tidak dapat dilihat sebagai suatu yang absolut atau bagian dari kenyataan hidup yang harus dipilih melainkan harus dilihat sebagai sistem nilai yang dapat dibedakan dan secara bergantian dapat dipilih sebagai prioritas di dalam pelaksanaan proses peradilan pidana.

Herbert L. Packer ${ }^{2}$ mengemukakan adanya dua Model, yakni Crime Control Model (CCM) dan Due Process Model (DPM). Kedua model ini menurut Packer, äkan memungkinkan seseorang memahami suatu anatomi yang normatif pada jantungnya hukum pidana. Model ini tidak menyebutkan mengenai apa kenyataannya dan apa yang seharusnya, kedua model ini bukanlah suatu polarisasi yang absolut.

Sebenarnya kedua model yang diajukan oleh Packer itu sangat erat hubungannya satu sama lainnya karena DPM itu sendiri pada hakikatnya merupakan reaksi terhadap CCM. Keduanya beroperasi dalam sistem peradilan pidana atau peroperasi di dalam Adversary

"Muladi dan Barda Nawawi. "Ruang Lingkup Penegakan Hukum Pidana dalam Konteks Politik Kriminal.". Makalah Seminar.Kriminologi. FH UNDIP Semarang tgl. II I3 November 1986. HIm.1.

${ }^{2}$ Herbert.I.Pakker.1968. The Limits of the Criminal Sanction. California: Stanford-University Press. HIm. 153. 
System (sistem perlawanan) yang berlaku di Amerika. Selain kedua model ini, terdapat pula model lain yakni model ketiga yang disebut Third Model atau Family Model yang dikemukakan oleh John Griffithst. ${ }^{3}$ Model terakhir ini adalah merupakan reaksi terhadap kedua model sebelumnya.

\section{Crime Control Model}

Crime Control Model (CCM) didasarkan pada pernyataan bahwa tingkah laku kriminil haruslah ditindak, dan proses peradilan pidana merupakan jaminan positif bagi ketertiban umum. Untuk mencapai tujuan yang amat tinggi ini, maka CCM menyatakan bahwa perhatian utama haruslah ditujukan pada efisiensi. Efisiensi di atas segalanya. Efisiensi mencakup kecepatan, ketelitian, dan daya guna administratif di dalam memproseskan pelaku tindak pidana. Setiap pekerjaan harus dilakukan dengan cepat dan harus segera seiesai. Oleh karena itu, proses tidak boleh diganggu dengan sederetan upacara serimonial dan mengurangi sekecil mungkin adanya perlawanan dari pihak lain karena hal itu hanya menghambat penyelesaian perkara.

Oleh Packer dikemukakan bahwa, ${ }^{4}$ doktrin yang digunakan oleh CCM adalah apa yang dikenal dengan nama presumtion of guilt (praduga bersalah). Dengan doktrin ini, maka CCM menekankan pentingnya penegasan eksistensi kekuasaan dan penggunaan kekuasaan terhadap setiap kejahatan dan pelaku kejahatan, dan karenanya pelaksanaan penggunaan kekuasaan pada tangan aparat pemerintah (polisi, jaksa dan hakim) harus semaksimal mungkin meskipun harus mengorbankan hak-hak asasi manusia.

\section{Due Process Model}

Model ini merupakan reaksi terhadap CCM. Model ini menitikberatkan pada hak-hak individu dan berusaha melakukan pembatasanpembatasan terhadap wewenang penguasa. Dengan kata lain, dapat dikatakan bahwa proses pidana harus dapat diawasi atau dikendalikan oleh hak-hak asasi manusia dan tidak hanya ditekankan pada maksimal efisiensi belaka seperti dalam CCM melainkan pada prosedur penyelesaian perkara. Pembatasan terhadap kekuasaan pemerintah ini mencerminkan ideologi atau cita-cita DPM yang mengandung authoritarian values ${ }^{5}$ atau anti cita-cita kesewenangan.

Berbeda dengan CCM yang didasarkan pada presumption of guilt, maka pada DPM didasarkan pada presumption of innocence sebagai dasar nilai sistem peradilan. Oleh DPM dituntut adanya suatu proses penyelidikan terhadap suatu kasus secara formal dan menemukan fakta secara objektif di mana kasus seorang tersangka atau terdakwa didengar secara terbuka di muka persidangan dan penilaian atas tuduhan penuntut umum baru akan dilakukan setelah terdakwa memperoleh kesempatan sepenuhnya untuk

3john Griffithst. "Ideology in Criminal." The Yale Law Joumal.Volume 79 No. 3. January 1970. HIm: 371-372. ${ }^{4}$ Herbert I. Pakker. Op.Cit. HIm. 160.

5John Griffithst. Op.Cit. Hlm. 363. 
mengajukan fakța yang 'membantah atau menolak tuduhan kepadanya. ${ }^{6} \mathrm{Jadi}$ yang penting . ialah pembuktian dalam pengadilan dan tuntutan 'bagaimana' akhir dari: suatu proses terhadap suatu kasus tidak begitu penting-daläm .DPM.

= Perlu diketahụ;; model-model yang dibicarakan -ini bukan: suatu_hal yangiabsolut yang' nampak 'dalam:kehidupan melainkan hanya merupàkan' values system yang muncul dalam sistem peradilan' pidana yang secara bergantian dàpatidipilih dalam sistem peradilan itu, misalnya' saja' dapat dilihat pada sistem peradilan pidana' Ameriká yàng 'tadinya didasarkàn pada CCM:namun sekarangyyang muncul 'dalam praktek adalah BPM; ,dan`ini kemudian berpengaruh 'kepada hukum: acara pidana dínegara-negara lain termasuk Indonesia, di mana hal-hal yang baik dari șistem DPM dimasukkan ke dalam hukum ẩcara pidana, 'misalnya pengacara'sudah dapat mendampingi-klien sejak ia 'ditangkap. , . :

\section{Family Model}

Family model adalah merupakan kritik terhadap kedua model, sebelumnya. John Griffithst; seorang guru besar dari Yale.Law School :University; di... California. yang mempelopori model ini mengatakan: Kedua model yang dikemukakan oleh Packer, apapun pembaharuannya :tetap berada !dalam rangka pemikiran suatu model yang disebut dengan System Adversary. atau :Battle Model:? Battle
Model (model perlawanan) memberikan gambaran bahwa proses kriminal merupakan suatu perjuangan atau merupakan suatu bentuk "peperangan yang khas": antara dua pihak yang kepentingannya satu sama lain berlawanan yaitu antara individu khususnya pelaku tindak pidana dan negara.

John Griffithst menggambarkan criminal justice system yang berlaku di Amerika sebagai suatu duel. ${ }^{8}$ yaitu antara terdakwa dengan negara dan pengacara dianggap sebagai tentara sewaan dan apabila seorang pengacara atau terdakwa dapat dibuktikan kesalahannya oleh jaksa dan dipidana, maka pihak pengacara di dalam peperangan itu dianggap telah kalah atau telah menyerah. Pada waktu polisi melakukan penangkapan dan memberikan peringatan/warming bahwa dia (tersangka) berhak dibantu oleh pengacara sebenarnya di situ sudah dimulai pernyataan perang oleh negara. Role of Law dari peperangan itu dalam bentuk hukum acara pidana pada hakikatnya dapat dijadikan sarana untuk mengatur taktik-taktik peperangan sedangkan fungsi hakim adalah untuk melihat (pasif) apakah peperangan itu dilakukan sesuai dengan aturan permainan. Gambaran yang ada ini sebagaimana mewarnai Battle Model menjadikan John Griffithst mengeritik keras terhadap Battel Model itu, yang ringkasnya mengatakan apapun bentuknya dari System Adversary itu, ia tetap berada dalam sistem peperangan yang tidak akan bisa mempertemukan dua

${ }^{6}$ Herbert L. Packer. Op.Cit. HIm. 163-164.

7 John Griffithct. Op.Cit. HIm. 267-268.

${ }^{8}$ John Griffithct. Loc Cit. 
kepentingan yang berlawanan (disharmonis of interest).

Adanya kepentingan yang tidak dapat dipertemukan Irreconciable disharmony of interest dan pernyataan perang yang merupakan nilai-nilai dasar dalam Due Process Model, adalah nilai-nilai dasar yang oleh John Griffithst dikehendaki untuk dibongkar sama sekali, dan diganti dengan sistem nilai berupa kepentingan yang saling mendukung dan menguntungkan menuju kesatuan harmoni, dan pernyataan kasih sayang sesama hidup yang disebut sebagai ideological staring point. ${ }^{9}$ Di dalam Family Model atau disebut juga model kekeluargaan yang sangat menonjol adalah pada konsep pemidanaan yang dapat digambarkan dalam padanan suasana suatu keluarga, yaitu bahwa apabila seorang anak telah melakukan kesalahan, maka akan diberikan sanksi, dengan tujuan anak tersebut mempunyai kesanggupan untuk mengendalikan dirinya akan tetapi setelah anak itu diberi sanksi, anak itu tetap perada dalam kerangka kasih sayang keluarga dan ia tidak dianggpnya sebagai anak jahat dan sebagai manusia yang khusus atau sebagai anggota kelompok yang khusus dalam kaitannya dengan keluarga.

Jadi Family Model adalah suatu perumpamaan yang ada dalam keluarga yakni meskipun salah satu keluarga dipukul, dijewer namun dia tetap dalam kasih sayang tanpa memperlakukan sebagai orang jahat yang khusus (special criminal puple). Demikian pula terhadap penjahat, jika ia dipidana janganlah dianggap sebagai special criminal puple yang kemudian diasingkan dari anggota masyarakat, namun. mereka itu tetap diperlakukan sebagai anggota masyarakat dan tetap dalam suasana kasih sayang. Inilah gambaran dari Family Model.

Dengan demikian apabila dibandingkan dengan Battle Model yang menganggap bahwa kriminal pada hakekatnya enemy of sosiety atau musuh dalam masyarakat dan fungsi dari pidana adalah xile of offender atau pengasingan pelaku kejahatan, maka terlihat bahwa nilai dasar dalam Battle Model itu tidak sesuai dengan nilai- nilai kekeluargaan dalam Famliy Model di mana fungsi punishment adalah sebagai oppealing capacity of self control atau berusaha mengendalikan agar supaya ia mempunyai kapasitas untuk memperbaiki diri, dan tetap berada dalam kerangka kasih sayang keluarga (continium of love).

Selain ketiga model yang telah dibicarakan di atas, Roeslan Saleh dengan bahasa dan istilah yang berbeda mengemukakan pula 2 model dalam peradilan pidana yaitu Model Yuridis dan Stuurmodel. Menurut Roeslan Saleh Jika diambil inti kedua model tersebut, maka dapat dikatakan sebagai berikut:

Menurut model yuridis tekanan diletakkan pada keadilan undang-undang, dan hakim sebagai puncak dari hirarki badan-badan kehakiman, sedang putusan hakim adalah faktor yang menentukan bagi penegakan hukum. Dia adalah sesuatu yang bersifat statisnormatif, dan banyak sedikitnya merupakan suatu sistem tertutup. Dalam stuurmodel tekanan diletakkan pada kegunaan sosial, tertib sosial, dan penegakan hukum sebagai

\%bid. HIm. 371. 
ungsi dari tertib sosial; sedangkan di antara Jadan-badan kehakiman ada kesamaan yang rinsipil. Dia merupakan suatu model dinamis, Jan terbuka bagi kenyataan-kenyataan sosial. ${ }^{10}$

Nampaknya apabila dikaji lebih jauh :erhadap model-model sebelumnya terutama ICM dan DPM, maka akan terlihat adanya jersamaan dengan model-model yang diajukan Roeslan Saleh tersebut di atas. Terlepas dari adanya persamaan, namun yang kerpenting adalah kesemua uraian di atas tèlah menunjukkan bahwa adanya berbagai model yang beroperasi dalam proses peradilan yang sekaligus meng'gambarkan sistem nilai yang mendasari proses peradilan itu.

\section{Faktor-Faktor yang Mempengaruhi Peradilan Pidana}

Lembaga Peradilan dibuat dengan tugastugas tertentu, sekurang-kurangnya bertugas menerima, memeriksa dan menyelesaikan setiap perkara yang diajukan kepadanya. Tujuannya adalah untuk melaksanakan dan menetapkan aturan hukum agar keadilan dapat diwujudkan kepada berbagai pihak.

Lembaga peradilan yang bertugas menyelenggarakan peradilan tidak dapat berbuat dan menghasilkan suatu karya tanpa mengkaitkan diri pada peran-peran dari berbagai komponen sosial dan lingkungan masyarakat yang membentuknya. Bekerjanya lembaga peradilan yang berpangkal dari kepentingan perseorangan dan kepentingan masyarakat sekitarnya memberi makna bahwa lembaga peradilan bukan suatu badan otonom di dalam masyarakat, melainkan diterima sebagai badan: yang merupakan bagian dari keseluruhan nilai-nilai dan prosesproses yang bekerja di dalam masayrakat tersebut. ${ }^{11}$

Dalam memahami lembaga peradilan seperti itu, mengisyaratkan pula pada suatu pengertian bahwa lembaga peradilan adalah bagian dari suatu sistem yang lebih besar, yakni sistem masyarakat, namun iapun merupakan sistem tersendiri terbatas dalam ruang lingkupnya. Oleh karena itu, lembaga peradilan dalam upayanya menghasilkan suatu out put memerlukan masukan-masukan baik yang berupa barang-barang (dalam konteks peradilan dimisalkan perkara pidana). Bahan-bahan masukan ini sedikit banyak mempengaruhi bentuk proses yang dijalankan peradilan serta hasil akhir dari proses itu.

Pada lain hal, terdapat pula berbagai faktor dan keadaan yang turut berperan dalam proses peradilan hingga dapat menghasilkan suatu keluaran (out put) atau apa yang disebut dengan putusan pengadilan. Di antara faktor dan keadaan tersebut merupakan masukan instrumental misalnya peraturan hukum, penegak hukum (hakim, jaksa, dan pengacara), dan fasilitas penunjang.

Atas dasar pendekatan system, maka dapat diduga bahwa faktor-faktor yang berperan di dalam proses penyelenggaraan. peradilan meliputi masukan mentah yang berupa perkara yang terjadi dan masukan in-

${ }^{10}$ Roeslan Saleh. 1983. Hukum Pidana sebagai Konfrontasi Manusia dan Manusia. Jakarta: Penerbit Galia. HIm. 15.

"Satjpto Rahardjo. Masalah Penegakan Hukum. Bandung: Sinar Baru. Hlm. 54. 
strumental berupa peraturan hukum, baik hukum acara maupun hukum materil, penegak hukum dan fasilitas atau sarana penunjang. Kesemua faktor tersebut akan diuraikan secara bèrturut-turut berikut ini.

\section{Faktor Perkara yang Terjadi}

Adalah suatu kenyataan, lembaga peradilan bukan pencipta perkara melainkan sebagai lembaga yang bertugas menyelesaikan perkara. Perkara yang terjadi inipun bukan atas keinginan lembaga itu, melainkan muncul dari mereka di luar lembaga tersebut, kehendak mengalihkannya perkara itu ke peradilan bukan pula aktivitas lembaga peradilan melainkan dari mereka yang menciptakan persoalan atau mereka yang sedang berperkara.

Dalam pemahaman sistem, perkara dipandang sebagai masukan mentah yang menjadi bahan olahan lembaga peradilan dalam menghasilkan out put yang diebut putusan. Apabila lembaga peradilan memperoleh masukan perkara menunjukkan isyarat untuk memulai bergerak memahami perkara yang diterimanya itu. Bentuk corak perkara yang diterima itu akan menentukan cara-cara peradilan dalam menanganinya.

Sesuai dengan jenis perkara pidana yang terbagi dalam tiga bentuk, yakni perkara biasa, perkara ringan, dan perkara sumir, maka lembaga peradilan harus menyelesaikan perkara tersebut berdasarkan jenis perkara yang diterimanya, sehingga apabila jenis perkara yang diterimanya adalah perkara biasa maka harus pula diselesaikan dengan beracara biasa, begitu pula yang diterima itu jenis perkara ringan maka harus pula diselesaikan dengan beracara ringan dan demikian seterusnya.
Lembaga pengadilan dalam menghasilkan keputusan-keputusannya akan dapat terjadi hanyalah dengan adanya perkara yang akan diajukan kepadanya. Pemanfaatan perkara termasuk kondisi-kondisi sosial disekitar perkara serta perhatian masyarakat berkenaan dengan perkara tersebut akan dapat lebih menjamin putusan pengadilan mengikat tidak saja kepada mereka yang bersengketa tetapi juga mengikat kepada semua orang berhak sama dengan pihakpihak yang tengah bersengketa.

Cukup beralasan bahwa cara penyelenggaraan perkara yang dijalankan oleh lembaga peradilan adalah didasarkan atas jenis perkara yang diterimanya, demikian pula putusan yang dihasilkan sedikit banyak bertumpuh dan ditentukan oleh bahan sengketa (perkara) yang masuk. Tanpa perkara masuk ke lembaga peradilan dengan sendirinya tidak akan ada proses dan putusan pengadilan, namun dengan perkara itu terjadilah proses dan putusan.

\section{Faktor Peraturan-Peraturan Hukum.}

Satu segi dari apa yang dinamakan negara berdasarkan atas hukum adalah senantiasa menselaraskan sikap dan perilaku setiap individu dengan keinginan-keinginan yang dirumuskan oleh hukum. Pada negara yang demikian itu, maka setiap perbuatan yang dilakukan hanya dapat dikatakan sah apabila perbuatan telah mendapat suatu legitimasi ataupun tetap berpedoman pada suatu aturan hukum.

Kehadiran hukum dalam pergaulan hidup di negara Pancasila ini tidak sekedar menunjukkan pada dunia luar bahwa negara ini berdasarkan atas hukum melainkan adanya kesadaran akan fungsi-fungsi yang 
ersemaian dalam diri hukum itu sendiri. dapun fungsi-fungsi hukum ini, Baharuddin opa menggambarkan sebagai berikut :12

Oleh karena itu sebagaimana halnya dengan agama, hukum pun merupakan as atool of social engeneering, seperti yang dikemukakan oleh seorang sosiolog hukum Rescoe Pound dan sosiolog pendidikan Karl Mannheim. Jadi hukum adalah kekuatan untuk mengubah masyarakat (change agent), bukan hukum yang berfungsi sekedar hanya sebagai penjaga malam, yaitu diam saja apapun yang terjadi disekelilingnya, sepanjang tidak terjadi pelanggaran hukum. Memang hukumlah yang akan bertindak kalau ada pelanggaran hukum atau tindak pidana, tetapi ia juga harus menciptakan kondisi sosial yang baru, yaitu dengan peraturanperaturan hukum yang diciptakan dan dilaksanakan, terjadilah social engineering, terjadilah perubahan sosial dari keadaan hidup yang serba terbatas menuju ke kehidupan hidup yang sejahtera atau keadaan hidup yang lebih baik. Lebih dari pada itu hukum juga berfungsi sebagai alat untuk mengecek benar tidaknya sesuatu tingkah laku ("as a tool of justification"). Dengan diketahuinya ciri-ciri kebenaran yang dikehendaki oleh hukum, maka dengan cepatlah mudah terlihat apabila ada sesuatu perbuatan yang menyimpang dari kebenaran itu. Akhirnya hukum berfungsi pula sebagai as tool of social control yaitu mengontor pemikiran dan langkah-langkah agar selalu terpelihara tidak melakukan perbuatan yang melanggar hukum.

\section{Gambaran yang dikemukakan} Baharuddin Lopa tersebut di atas menunjukkan adanya tiga fungsi hukum, secara singkat meliputi: as a tool of social (sebagai alat perubahan sosial), as a tool justification (sebagai alat mengecek benar tidaknya tingkah laku), dan as a tool of social control (ssebagai alat kontrol sosial). Dengan memperhatikan fungsi hukum ini, dapat diketahui bahwa peraturan hukum yang beroperasi di lembaga peradilan selain in put instrumen memberi pula legitimasi pengadilan untuk melakukan peradilan. Lebih dari itu dengan peraturan hukum yang ada, lembaga peradilan dapat menentukan suatu perbuatan. yang dianggap benar dan yang tidak benar, serta memberikan sanksi kepada perbuatan yang dianggap tidak benar itu.

Peranan peraturan hukum dapat pula terlihat pada saat lembaga peradilan sedang memproses suatu perkara. Peranan peraturan hukum di sini adalah menjadi pedomàn dalam menyelesaikan setiap perkara yang dihadapinya. Kitab Undang-Undang Hukum Acara Pidana (KUHAP) dan. Undang-Undang Peradilan lainnya adalah suatu pedoman yang nyata bagi lembaga peradilan. Sudah barang tentu dengan adanya pedoman itu maka proses peradilan akan menjadi tertib, lancar dan teratur sehingga ..pada gilirannya

12Baharuddin Lopa. 1987. Permasalahan Pembinaan dan Penegakan Hukum Di Indonesia. Jakarta: Penerbit Bulan Bintang. HIm. 32. 
diharapkan akan melahirkan suatu keputusan hukum yang dapat diterima semua pihak.

Selanjutnya undang-undang tidak hanya sekedar memberi pedoman bagi pengadilan, tetapi juga undang-undang juga memberikan kesempatan yang luas untuk menerapkan hukum menurut keyakinannya dalam hal-hal undang-undang: sendiri tidak memberi ketentuan-ketentuan . Bahkan menurut Kartono, undang-undang juga memberikan wewenang kepada para hakim untuk dalam hal-hal istimewa, menurut kebijaksanaannya yang bebas menyimpang dari suatu ketentuan undang-undang. Dicontohkan, hakim menurut penilaiannya sendiri bebas dapat menyimpang (delinguet; bahasa latin delingquere, berbuat salah=melakukan tindak pidana) itu belum mencapai umur 16 tahun. ${ }^{13}$

\section{Faktor Penegak Hukum}

Penyelenggaraan peradilan khususnya pada tingkat pengadilan tidak dapat pula mengabaikan peran penegak hukum. Posisi penegak hukum pada proses penyelenggaraan peradilan adalah sangat dominan karena semua input yang masuk ke dalam proses tersebut baru dapat memberi andil pada out put manakala telah mendapat pengolahan terlebih dahulu dari penegak hukum.

Penegak hukum yang dimaksud dalam pembahasan ini adalah terbatas pada Jaksa penuntut umum, Hakim dan Pengacara. Adapun Polisi yang juga tergolong sebagai penegak hukum pembahasannya tidak diperlukan mengingat pembicaraan kita pad: bagian ini hanya terbatas pada prose peradilan di tingkat pengadilan, di mana Polis tidak terlibat secara langsung di dalamnya.

Pembicaraàn penegak hukum (jaksə hakim dan pengacara) sebagai faktor yan! berperan dalam. proses peradilan pidan: dapat dikaitkan dengan melihat tugas da wewenang masing-masing penegak hukur tersebut di dalam mekanisme bekerjany lembaga peradilan. Jaksa penuntut umum Hakim dan Pengacara merupakan sub sisten dari sistem peradilan, meskipun kesemuany: digolongkan sebagai penegak hukum namur tugas dan wewenang dalam proses peradilar adalah berbeda satu sama lainnya. Di bawar ini akan dijelaskan bagaimana tugas dar wewenang masing-masing penegak hukum itu dalam kaitannya dengan proses peradilar pidana pada tingkat pengadilan.

Pada setiap perkara pidana terutame perkara pidana biasa yang sedang diproses di pengadilan senantiasa memperlihatkan suatu keadaan di mana setelah Hakim membuka sidang, Jaksa penuntut umum dipersilahkan untuk membacakan surat dakwaan. Pembacaan ini adalah wajar sebab di tangan Jaksa penuntut umumlah diserahkan tugas 'membuat surat dakwaan. Surat dakwaan ini adalah sangat penting dalam proses perkara pidana, sebab surat dakwaan akan dijadikan dasar oleh Hakim untuk menentukan proses lebih lanjut. Tugas dan wewenang Jaksa penuntut umum lainnya adalah mempersiapkan alat-alat bukti terutama benda-benda dan bebrapa saksi.

${ }^{13}$ Kartono. 1982. Peradilan Bebas. Jakarta: Penerbit Pradnya Paramita. HIm. 62. 
Alat-alat bukti ini tidak lain adalah untuk membuktikan bahwa apa yang dikatakan Penuntut Umum dalam surat dakwaannya itu adalah sesuatu yang benar.

Selain tugas Jaksa,Penuntut umum tersebut di atas, pembuatan Requisitoir ${ }^{14}$ dan membacakannya di depan sidang pengadilan adalah juga merupakan tugas pokok dan tetap yang harus dijalankannya. Requisitoir dibuat dan dibacakan setelah pemeriksaan alat-alat bukti dan terdakwa. Tugas Jaksa penuntut umum di dalam persidangan akan berakhir setelah menanggapi pledoi (pembelaan yang diajukan terdakwa atau penasihat hukumnya). Tugas terakhir ini adalah tugas mengajukan replik (tanggapan atas pledoi).

Dari uraian di atas dapat dipahami betapa berperannya Jaksa penuntut umum dalam suatu proses peradilan. Peranan Jaksa penuntut umum ini tidak hanya sekedar bagaimana proses persidangan itu menjadi lancar melainkan juga sangat membantu hakim dalam menjatuhkan putusan. Apa yang diungkapkan dan diajukan oleh Jaksa penuntut umum merupakan bagian yang terpenting bagi pertimbangan Hakim. Dengan demikian hasil akhir dari porses peradilan adalah juga merupakan bagian yang "tak terpisahkan dari buah tangan dan pikiran Jaksa penuntut umum.
Penegak hukum lainnya adalah Hakim; peranan Hakim tidak kalah bila dibanding. dengan Jaksa Penuntut umum. Bahkan dapat dikatakan bahwa peranan :Hakim justru lebih penting dan sangat berat sebab Hakimlah yang senantiasa mengatur tahapan-tahapan yang harus dilalui dalam proses persidangan, termasuk di dalamnya mengatur kelancaran dan ketertiban sidang. Dengan kata lain keseluruhan dari tahapan proses adalah di bawah tanggung jawab dan kepemimpinan Hakim, termasuk diantaranya melahirkan apa yang disebut dengan putusan yang. kemudian kita sebut sebagai out put pengadilan.

Di awal sidang pengadilan, tugas pertama bagi Hakim adalah membuka sidang dengan menyatakan "Sidang di buka dan terbuka untuk umumn, kemudian memerintahkan kepada Jaksa penuntut umum untuk memanggil tersangka masuk ke dalam sidang. Setelah tersangka dihadapkan, tugas Hakim selanjutnya adalah memeriksa identitas tersangka. Setelah pemeriksan identitas tersangka, hakim meminta kepada Jaksa penuntut umum membacakan surat dakwaannya, kemudian diteruskan dengan pemeriksaan saksi-saksi dan barang-barang bukti. Tugas Hakim dalam pemeriksaan saksi adalah berusaha memperoleh keterangan saksi berdasarkan atas apa yang didengar

${ }^{14}$ Requisitoir digunakan sebagai pengganti isitlah tuntutan pidana yang digunakan oleh KUHAP, Penulis tidak menggunakan istilah "tuntutan pidana" karena bila menggunakan "tuntutan pidana" "berarti penutut umum diharuskan mengajukan permohorian putusan berupa pidana, sementara dalam praktek persidangan tidak selamanya setelah proses pembukktian penuntut mengajukan permohonan pidana melainkan mengajukan permohonan putusan bebas, seperti terhadap terdakwa Iwik dalam kasus Udin, atau melepaskan terdakwa dari hukuman. Dengan demikian tidak relevan jika menggunakan tuntutan pidana pada kondisi yang demikian itu. Oleh karena itu lebih tepat menggunakan Requisitoir, yakni kesimpulan penuntut umum dari hasil pemeriksaan di persidangan yang diseertai dengan permohonan kepada hakim agar menjatuhkan putsuan kepada terdakwa 
sendiri, dilihat dan dialami langsung oleh saksi dan berusaha mencocokkan dan menilai antara keterangan saksi satu dengan keterangan saksi lainnya serta dengan barangbarang bukti. Di samping itu berusaha minta keterangan yang dipandang perlu untuk mendapatkan kebenaran. Pada akhir proses peradilan, maka puncak dari keseluruhan tugas Hakim adalah menyusun putusan kemudian membacakannya putusannya itu dalam suatu sidang yang terbuka untuk umum.

Dengan gambaran tugas Hakim tersebut maka jelas pula betapa pentingnya peranan Hakim dalam proses peradilan pidana di tingkat pengadilan. Sudah barang tentu tanpa hadirnya Hakim, proses penyelenggaraan peradilan pidana tidak akan terjadi, dan tidak akan muncul pula putusan peradilan itu.

Bagaimana dengan Pengacara? Peranan Pengacara di akui tidak sepenting dengan peranan Penuntut umum maupun Hakim. Namun demikian tidak berarti bahwa pernan Pengacara dalam penyelenggaraan peradilan pidana sama sekali tidak ada. Peranan Pengacara mulai terasa ketika perkara yang disidangkan terdakwanya diancam dengan pidana mati atau ancaman pidana 15 tahun atau bagi mereka yang tidak mampu yang diancam dengan pidana 5 tahun atau lebih. Perkara yang demikian mengharuskan hadirnya seorang Pengacara dan apabila terdakwa tidak mempunyai Pengacara sendiri, pejabat yang bersangkutan pada semua tingkatan pemeriksaan dalam proses peradilan wajib menunjuk Penasihat Hukum bagi mereka (Pasal 56 KUHAP).

Penyelenggaraan peradilan pidana dengan menghadirkan terdakwa yang berkualifikasi seperti di atas dibutuhkan hadirnya Pengacara. Sasaran menghadirkan Pengacara selain untuk memenuhi Pasal 56 KUHAP tersebut diatas, juga adalah memberi bantuan hukum bagi terdakwa serta membantu Hakim dalam menemukan kebenaran hukum yang berintikan keadilan. Wujud bantuan hukum bagi terdakwa di dalam persidangan adalah pembuatan eksepsi, pledoi dan duplik.

\section{Faktor Pasilitas atau Sarana Penunjang}

Penyelenggaraan peradilan pidana di tingkat pengadilan nampaknya tidak sekedar membuthkan masukan baik berupa perkara, peraturan hukum ataupun aktivitas para penegak hukum, melainkan sangat membutuhkan pula masukan-masukan lain berupa fasilitas atau sarana penunjang yang secara sederhana dapat dirumuskan, sebagai sarana untuk mencapai tujuan. ${ }^{15}$ Fasilitas yang dimaksud antara lain kertas, karbon, mesin tik, komputer, alat-alat komunikasi, ruang sidang, kendaraan, keuangan da lain-lainnya.

Fasilitas tersebut meskipun sebagai penunjang, namun peranannya tidak dapat diabaikan. Sebab bagaimana Hakim akan dapat menyusun putusan dan bagaimana pula Penuntut umum dan Pengacara menyusun surat dakwaan dan pledoi dengan baik seandainya tidak tersedianya kertas, karbon dan mesin tik atau komputer. Demikian pula

${ }^{15}$ Soerjono Soekanto dan Mustafa Abdullah. 1980. Sosiologi Hukum dalam Masyarakat'. Jakarta: Penerbit Rajawali. HIm. 17. 
tagaimana peradilan pidana berjalan lancar ka dana (honor, uang saksi, uang operasionàl dili) serta alat-alat komunikasi dan transportasi idak tersedia untuk itu. Sudah dapat tibayangkan bahwa seandainya tidak adanya tau kurangnya fasilits atau sarana penunjang ersebut penyelenggaraan peradilan pidana kkan mengalami hambatan dan bahkan bisa Jerakibat kemacetan.

Oleh karena itu faktor fasilitas tidak dapat Jiabaikan, justru sebaliknya ia harus mendapat empat dan harus mendapat perhatian akan <elengkapannya. Fasilitas yang lengkap dan erpelihara dengan baik sangat membantu jetugas-petugas hukum di dalam nenjalankan tugasnya 'masing-masing, :erutama di dalam menetrapkan peraturan secara resmi. Pelaksanaan tugas yang Jidukung oleh fasilitas yang baik otomatis akan ebih melancarkan tugas tersebut, demikian jula tugas menyelenggarkan peradilan' pidana akan berjalan dengan baik dan mampu menghasilkan putusan yang baik jika fasilitas Jan sarana mendukungnya.

Karena faktor fasilits ini berperan dalam penyelenggaraan peradilan pidana baik di sidang pengadilan maupun pemeriksaan sebelum sidang maka faktor ini perlu dipikirkan yang disandarkan pada hal-hal sebagai berikut: ${ }^{16}$

1. apa yang sudah ada dipelihara terus agar setiap saat berfungsi?

2. apa yang belum ada, perlu diadakan deñgan memperhitungkan jangka waktu pengadaannya?
3. apa yang kurang perlu dilengkapi?

4. apa yang macet dilancarkan? dan,

5. apa yang telah mundur ditinggalkan?

Keseluruhan uraian yang telah dijelaskan di muka menunjukkan bahwa faktor-faktor yang berperan di dalam penyelengaraan peradilan pidana di tingakt pengadilan adalah meliputi perkara, peraturan hukum, penegk hukum, dan fasilitas yang mendukung. Keempat faktor ini tidak dapat dipisahkan apalagi ditinggalkan sebab, bila salah.satu tidak berfungsi atau diabaikan akan berakibat macetnya peranan pada faktor lainnya. Oleh karena itu, keempat faktor ini mutlak ada. Sejalan dengan itu Chambliss \& Seidman memerinci lebih luas adanya berbagai faktor yang mempengaruhi penyelenggaraan peradilan. Diàntara faktor-faktor tersebut adalah:17

1. Bahan-bahan (the way in which the issues are presenterd)

2. Kebijakan yang dipilith (policy)

3. Ciri sosial dari pribadi-hakim (the personal attribute of the judge)

4. Sosialisasi profesional hakim (the professional socialization of the judge)

5. Kendala keadaan (situasional pessure on the judge)

6. Kendala organiasi (organizational pressure in him)

7. Alternatip-alternatip peraturan yang dapat dipakaiakan (alternative permissiable rules of law).

${ }^{16} /$ bid. Hlm. 16.

${ }^{17}$ William J Chamliss \& Roberto Seidman. 1971. Law, Order and Power. Massachusetts: Addison Wesley Publishing Company. HIm. 90-107. 
Demikianlah maka, berfungsi tidaknya penyelenggaraan peradilan pidana dalam menghasilkan out put berupa putusan adalah sangat tergantung dari hubungan yang serasi antara berbagai fáktor-faktor tersebut. Dan berkualitas tidaknya out put yang dihasilkan tergantung pula kepada berkualitas tidaknya keseluruhan factör yang terdapat di dalam proses peradilan pidana itu.

\section{Simpulan}

Penyelenggaraan peradilan pidana dalam konteks penegakan hukum pidana tidak lain dimaksudkan sebagai suatu kebijakan dalam upaya menaggulangi kejahatan sehingga proses-ṕroses pembangunan dalam usaha mensejáhterakan rakyat dapat tercapai. Dalam penyelènggaraan peradilan pidana tidak lepas dengan model-model yang berkembang dalam setiap sistem peradilan pidana. Modelmodel ini bukan sesuatu yang kongkrit melainkan sesuatu yang abstrak karena merupakan abstraksi dari nilai-nilai yang ada. Pilihan terhadap satu model tergantung kepada nilai-nilai apa yang akan dijalankan dalam peradilan, dan dalam penyeleggaraan peradilan tidak menutup kemungkinan pada kurun waktu tertentu menggunakan model silih berganti atau mungkin pula menggunakan secara bersama-sama sekalipun secara tidak terang-terangan diakui dalam peraturan perundang-undangan.

Penyelenggaraan peradilan pidana tidak dapat pula dilepaskan dari berbagai faktor yang mempengaruhinya. Terdapat beberapa faktor yang berperan dalam penyelenggaraan peradilan itu antara lain yang terpenting adalah faktor perkara, penegak hukum, peraturan perundang-undangan, dan faktor sarana prasarana. Keseluruhan faktor ini tidak dape dipisahkan satu sama lain apa lagi diabaikar karena jika diabaikan, maka akal mempengaruhi hasil akhir dari prose. peradilan itu. $\square$

\section{Daftar Pustaka}

Chamliss, William J \& Roberto Seidman. 1971 Law, Order and Power. Massachusetts Addison Wesley Publishing Company.

Griffithst, John. "Ideology in Criminal." The Ya?." Law Journal. Volume 79 No. 3. Januar: 1970.

Kartono. 1982. Peradilan Bebas. Jakarta Penerbit Pradnya Paramita.

Lopa, Baharuddin. 1987. Permasalahat Pembinaan dan Penegakan Hukun Di Indonesia. Jakarta: Penerbit Bular Bintang.

Muladi dan Barda Nawawi. "Ruang Lingkuf Penegakan Hukum Pidana dalam Konteks Politik Kriminäl." Makalar Seminar Kriminologi. FH UNDIF Semarang tgl. II I3 November 1986.

Pakker, Herbert.J. 1968. The Limits of the Criminal Sanction. California. Stanford-University Press.

Rahardjo, Satjipto. Masalah Penegakan Hukum. Bandung: Sinar Baru.

Saleh, Roeslan.1993. Hukum Pidano sebagai Konfrontasi Manusia dar Manusia. Jakarta: Penerbit Galia.

Soekanto, Soerjono dan Mustafa Abdullah. 1980. Sosiologi Hukum dalam Masyarakat". Jakarta: Penerbi Rajawali. 